\title{
ЗАСТОСУВАННЯ МЕТОДУ ГРУПОВОГО УРАХУВАННЯ АРГУМЕНТІВ ДЛЯ ПОБУДОВИ АЛГОРИТМІВ ДІАГНОСТИКИ ІШЕМІЧНОЇ ХВОРОБИ СЕРЦЯ
}

\author{
Настенко . ${ }^{1,2}{ }^{1,2}$, с.н.с., д.б.н., к.т.н. \\ nastenko.e@gmail.com \\ Максименко В.Б. ${ }^{1,2}$, проф., д.м.н. \\ maksymenko.vitaliy@gmail.com \\ Поташев С.В. ${ }^{2}$, доц., к.М.н. \\ potashovsv77@gmail.com \\ Павлов В.А. ${ }^{1}$, доц., к.т.н. \\ pavlov.vladimir264@gmail.com \\ Бабенко В.О. ${ }^{1}$, магістр \\ vbabenko2191@gmail.com \\ Рисін С.B. ${ }^{1,2}$, ст. викл. \\ drunk umka@yahoo.com \\ Матвійчук O.B. ${ }^{1}$, аспірант \\ sasha.matviich@gmail.com \\ Лазоришинець В.В. ${ }^{2}$, проф., д.М.н. \\ lazorch@ukr.net \\ ${ }^{1}$ Національний технічний університет України \\ “Київський політехнічний інститут імені Ігоря Сікорського”, \\ м. Київ, Україна \\ ${ }^{2}$ Національний інститут серцево-судинної хірургії імені М.М. Амосова, \\ м. Київ, Україна
}

Pеферат - Проблематика. Метод групового урахування аргументів є доволі недооціненим інструментом для отримання високоточних прогностичних моделей. Перший варіант штучної нейронної мережі (які користуються величезною популярністю в світі машинного навчання) був отриманий в 1965 році українським вченим Олексієм Івахненко, який як раз використовував метод групового урахування аргументів для навчання мережі. Відомо, що даний підхід має місце фактично в будь-якій проблематиці, і не виключенням $\epsilon$ задача розпізнавання ішемічної хвороби серця по відеоданим спекл-трекінг ехокардіографії. Вирішення подібної задачі $є$ актуальним, оскільки це надасть можливість аналізувати ехокардіограми навіть якщо вони не оснащені технологією спеклтрекінг.

Мета. Методом групового урахування аргументів за даними спекл-трекінг ехокардіографії побудувати класифікаційні алгоритми діагностики порушень кінематики скорочень лівого шлуночка серця у хворих на ішемічну хворобу серця в умовах стану спокою, та при застосуванні ехострестесту із добутаміновою пробою.

Методика реалізації. Національним інститутом серцево-судинної хірургії імені М.М. Амосова були надані відеодані, отримані за допомогою методу спекл-трекінг ехокардіографії, яким було обстежено 56 пацієнтів 3 підозрою на ішемічну хворобу серця. Серед них лише у 16 пацієнтів патологію виявлено не було. Ехокардіографія реєструвалась у В-режимі за трьома позиціями: довгої вісі, 4камерної та 2-камерної позиціях. Усього для дослідження було використано 6245 кадрів відео потоку: 1871 - без порушень серцевої діяльності, та 4374 - при наявності патології під час обстеження.

Результати дослідження. Методом групового урахування аргументів було одержано 12 моделей класифікації з урахуванням доз добутаміну $(0,10,20$ і 40 мкг), точність яких на екзаменаційній вибірці варіювалась від 81.7\% до 97.4\%. Також були отримані 3 моделі класифікації без урахування доз добутаміну, які на екзаменаційній вибірці показали точність в межах 75.2-82.2\%.

Висновки. Отримані високоточні моделі класифікації методом групового урахування аргументів. Дані моделі можна буде застосувати для аналізу ехокардіограм, отриманих у В-режимі на обладнанні, яке не оснащене технологією спекл-трекінг.

Ключові слова: метод групового урахування аргументів; класифікація; спекл трекінг ехокардіографія; ехострестест з добутаміном; ішемічна хвороба серия. 


\section{I. ВСТУП}

На сьогоднішній день область комп'ютерного зору [1] займає провідне місце в науці. Основна ціль даної області полягає в тому, щоб із зображення отримати необхідну інформацію для розпізнавання та класифікації об'єктів. Подібними об'єктами можуть виступати серця людей. 3 використанням сучасних розробок в машинному навчанні [2] існує можливість розпізнавання патології за зображеннями серця. Все що для цього необхідно - дані зображення отримати.

Національним інститутом серцево-судинної хірургії імені М.М. Амосова (рис. 1) були надані відеодані спекл-трекінг ехокардіографії (СТЕ).

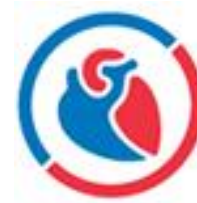

НАЦІОНАЛЬНИЙ ІНСТИТУТ СЕРЦЕВО-СУДИННОÏ ХІРУРГІІ IMEHI M. M. AMOCOBA

Рис. 1. Логотип Національного інституту серцевосудинної хірургії імені М.М. Амосова Джерело: http://amosovinstitute.org.ua/

СТЕ використовується для визначення типу деформації міокарду (нормальної чи патологічної) при ішемічній хворобі серця пацієнта [3-4]. Даний метод в купі зі застосуванням стрес-тестів 3 добутаміном вважається доволі потужним способом визначення латентних порушень роботи серця. Маючи подібну особливість представляється

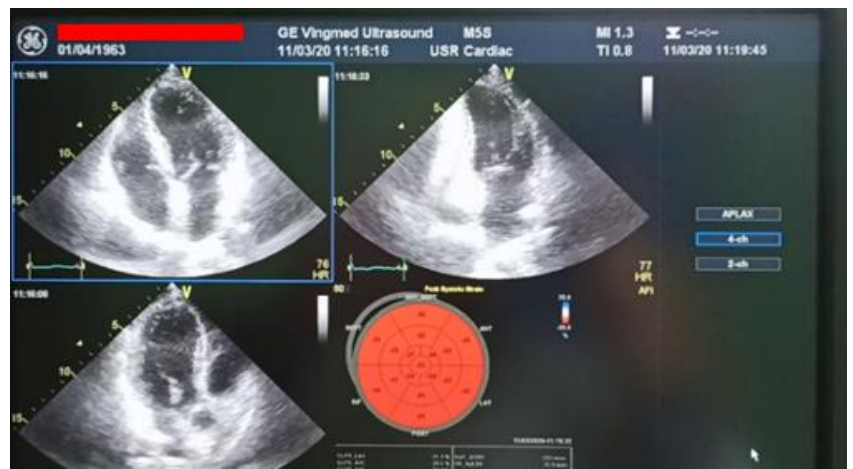

a) можливим вдосконалити діагностування серця за допомогою вище вказаного машинного навчання. Саме ця задача i була покладена на авторів роботи із кафедри біомедичної кібернетики Національного технічного університету України "Київський політехнічний інститут імені Ігоря Сікорського”.

В дослідженні детально пояснюється, яким чином були отримані інформативні ознаки із СТЕ, причини використання методу групового урахування аргументів (МГУА) [5-6] та отримані результати.

\section{II. ПОСТАНОВКА ЗАДАЧІ}

Метою роботи було отримати алгоритми діагностики ішемічної хвороби серця за даними CTE із застосуванням добутамінової проби за допомогою МГУА.

\section{III. ОПИС КЛІНІЧНИХ ДАНИХ}

Для проведення дослідження були надані відеодані СТЕ. Всього їх налічено 154 екземпляри Застосування подібної технології проводиться 3 реєстрацією ехокардіограми (ЕКГ) у В-режимі по інформативним проекціям серця.

Досліджувався стан 56 пацієнтів з підозрою на ішемічну хворобу серця (у 16 із них під час обстежень не було виявлено порушень кінематики). Різницю між СТЕ здорової людини та СТЕ хворої більш детально зображено на рис. 2.

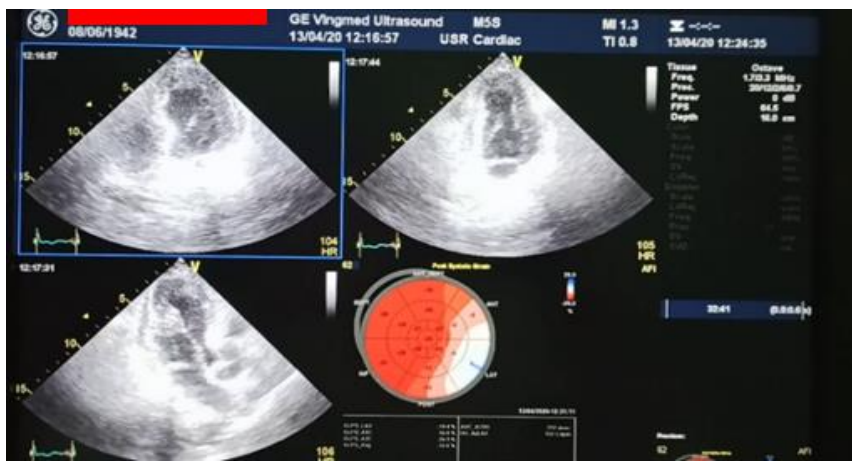

б)

Рис. 2. а) СТЕ серця в нормі (коло повністю червоне, всі сегменти лівого шлуночка серця (ЛШС) функціонують нормально); б) СТЕ при патології серця (коло змінює колір, стрейни деяких сегментів ЛШС патологічно змінені) Джерело: Національний інститут серцево-судинної хірургії імені М.М. Амосова

Для того, щоб працювати з такими даними, було вирішено розбити відео СТЕ на кадри (фрейми). Кожен кадр розглядався як окремий об'єкт дослідження. Усього було виділено 6245 подібних фреймів: 1871 фреймів серця в нормі та 4374 - патології.
Крім того, за згодою пацієнтів під наглядом анестезіолога застосувався ехострестест 3 різними дозами добутаміну (10, 20 і 40 мкг). Дана проба припинялась при появі мінімальних ознак дискомфорту чи порушень серцевої діяльності. Як було сказано раніше, подібна 
практика використовувалась як додатковий спосіб виявлення ішемічної хвороби серця. 356 обстежених пацієнтів (усього 2509 фреймів СТЕ) ехострестест із добутаміновою пробою застосовували на 38 (3736 фреймів) при умові, що порушень в стані спокою виявлено не було.

Слід також додати, що СТЕ у В-режимі реєструвалась в трьох позиціях [3-4]: по довгій вісі, у 4-камерній та 2-камерній позиціях (рис. 3).

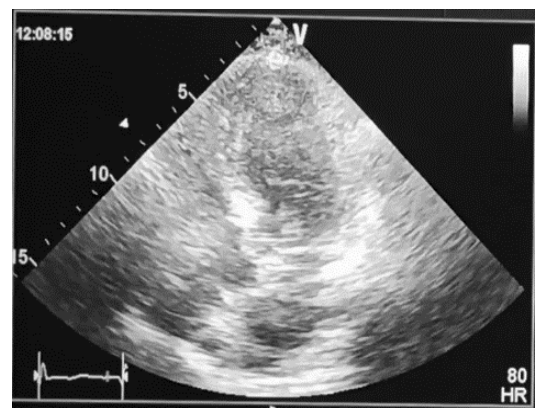

a)

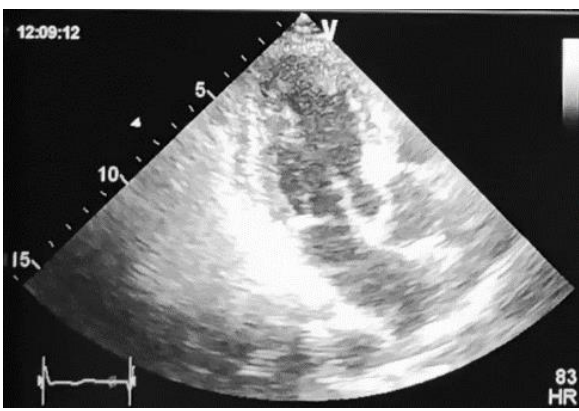

б)

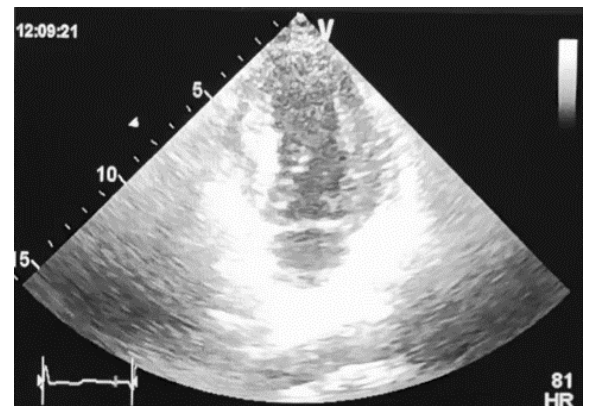

B)

Рис. 3. а) проєкція СТЕ №1 - поздовжня вісь; б) проєкція №2 - двокамерна проєкція; в) проєкція №3 - 4-камерна позиція

Джерело: Національний інститут серцево-судинної хірургії імені М.М. Амосова

Для отримання додаткової інформації під час дослідження дані позиції були вирізані окремо, таким чином сформувавши три вибірки даних.

\section{IV. КОНСТРУЮВАННЯ ОЗНАК}

Конструювання ознак (Feature Engineering) [7] полягає відповідно у отриманні інформативних ознак, за якими можна виконувати моделювання даних. Це дуже актуально у відношенні до зображень, оскільки зазвичай надто важко отримати їхні певні метадані. Крім класу зображення (мітка: норма чи патологія) та частоти серцевих скорочень (ЧСС) про надані СТЕ більше даних немає. Для отримання повної інформації про зображення можна застосувати методи текстурного аналізу [8-9].

Подібні методи були успішно застосовані деякими 3 авторів із кафедри біомедичної кібернетики в роботах [10-11], які стосувались класифікації зображень ультразвукового дослідження (УЗД) печінки та магнітнорезонансної томографії (МРТ) мозку. Не слід також забувати про досвід інших авторів, які детально розписані в роботах [12-13].

Основна ідея текстурного аналізу полягає в отримані певних інформативних (більшою мірою пов'язаною зі статистикою) ознак на основі так званих матриць градацій сірого. Ці матриці $\epsilon$ математичним представленням зображень розміром $n \times \mathrm{x}$. Кожне значення матриці, що на зображенні представляється у вигляді пікселю, означає відтінок сірого від 0 (чорний колір) до 255 (білий колір). Крім стандартних статистичних характеристик (середнє значення, медіана, дисперсія, тощо) на основі даних матриць можуть рахуватись статистики другого порядку, такі як GLCM, GLRLM і т.п. [14].

Для даного дослідження були взяті деякі методики, які вже використовувались авторами в роботах [10-11], а саме:

1. Гістограмне перетворення зображень за допомогою двох типів диференціації (горизонтального і вертикального).

2. Розрахунок на основі отриманих після перетворення зображень статистичних показників [15]:

a) середнє значення градацій сірого:

$$
\text { mean }=\overline{g_{i, j}}=\frac{1}{n} \sum_{1}^{n} g_{i, j}
$$

b) середньоквадратичне відхилення:

$$
s t d=\sqrt{\frac{1}{n} \sum_{1}^{n}\left(g_{i, j}-\text { mean }\right)^{2}}
$$

c) асиметрія:

$$
\text { skew }=\frac{\sum_{1}^{n}\left(g_{i, j}-\text { mean }\right)^{3}}{(n-1) \cdot s t d^{3}}
$$

d) ексцес:

$$
k u r t=\frac{\sum_{1}^{n}\left(g_{i, j}-\text { mean }\right)^{4}}{(n-1) \cdot s t d^{4}}
$$


e) pозмах:

$$
\text { range }=g_{\max }-g_{\min }
$$

f) медіана (median), перший квартиль (Q1), третій квартиль (Q3), 5-перцентиль (P5), 95перцентиль (Р95), міжквартильний розмах (IQR).

3. Розрахунок подібних ознак на матриці GLRLM.

3 врахуванням ЧСС в сумі було отримано 87 інформативних ознак, які застосовувались для подальших досліджень.

\section{V. ПРОЦЕС МОДЕЛЮВАННЯ}

Для отримання моделей зображень СТЕ було використано змішаний покроковий підхід МГУА [16]. Причина використання даного підходу полягала в тому, що вони є більш рентабельними в порівнянні 3 класичними методами машинного та глибокого навчання [17] для моментальної демонстрації результату прогнозування стану серця під час СТЕ діагностування. Це пов'язано з використанням для цього особливої форми нелінійної регресії, де в якості результату виступає неперервне значення не в межах $[-\infty ;+\infty]$, а в межах $[0 ; 1]$. Якщо отримане значення менше 0.5 , то об'єкту привласнюється перший клас, в іншому випадку другий. Використання таких моделей також дає можливість виявити найбільш значимі ознаки, що дає додаткову перевагу під час діагностики.

Ідея змішаного покрокового МГУА наступна: спочатку випадковим чином вибірка багаторазово ділиться на навчальну (70\% - для навчання моделі), тестову та екзаменаційну (20\% та $10 \%$ відповідно - для визначення отриманої якості моделі). Тестова вибірка необхідна для підбору оптимальної структури моделі, а на екзамені відбувається вже об'єктивна оцінка отриманої результуючої моделі. Потім відбирається модель 3 найкращими показниками за тестовою та екзаменаційною вибірками. Характеристиками якості моделей були точність, чутливість та специфічність за тестовими вибірками, а також коефіцієнт кореляції Метьюза (ККМ).

Слід зазначити, що остання характеристика [18] була запропонована біохіміком Брайаном Меттьюзом в 1975 році, але більшу популярність вона здобула недавно. Деякі дослідники даних та фахівці 3 машинного навчання вважають ККМ оптимальною характеристикою якості моделі класифікації, оскільки вона бере до уваги одночасно усі результати, і не залежить від співвідношення між класами. ККМ обраховується за формулою:

$$
W=\frac{T P \times T N-F P \times F N}{\sqrt{(T P+F P)(T P+F N)(T N+F P)(T N+F N)}}
$$

де: ТР (True Positives) - кількість правильних передбачень першого класу, FP (False Positives) - кількість неправильних передбачень першого класу (помилка першого роду), FN (False Negatives) - кількість неправильних передбачень другого класу (помилка другого роду), TN (True Negatives) кількість правильних передбачень другого класу.

Далі відбувається метод прямого відбору, тобто зі списку всіх можливих вхідних змінних (включаючи їхні нелінійні перетворення та комбіновані змінні) вибирається та, яка має найбільшу кореляцію з вихідною змінною, після чого модель, яка містить лише одну обрану незалежну змінну, перевіряється на значущість за допомогою приватного F-критерію на навчальній вибірці. Якщо значимість моделі не підтверджується, то алгоритм на цьому закінчується через брак суттєвих вхідних змінних. В іншому випадку ця змінна вводиться в модель і здійснюється перехід до наступного пункту алгоритму. Слід зазначити, що в даному випадку перевірка на значимість всієї моделі в цілому буде рівносильна перевірці на значущість обраної незалежної змінної, тому що на даному етапі модель ще не містить інших вхідних змінних.

Після включення нової змінної в модель здійснюється перевірка на значимість інших змінних, які вже були введені в неї раніше. У разі, якщо такі незначущі змінні будуть виявлені, їх слід вивести зі складу моделі.

Після корегування списку включених в модель змінних здійснюється чергова ітерація процедури прямого відбору 3 пошуку нової змінної, що задовольняє умовам включення ії до складу моделі. Слід зазначити, що отримувана модель на кожній ітерації запам'ятовується, і включається в список “моделей-кандидатів". Даний процес повторюється до тих пір, поки не перевірені усі змінні. Після того як формується повний список кандидатів, кожна модель перевіряється на тестовій вибірці, і обирається та, яка дає найкращий результат на ній, таким чином відбувається селекція найкращих моделей. 


\section{VI. РЕЗУЛЬТАТИ}

Для побудови моделей було використано програмне забезпечення GMDH Shell DS [19] версії 3.8.9. Моделі були побудовані у два етапи: з урахуванням доз добутаміну, а також без його урахування, у бінарній шкалі "нормапатологія".

\section{1. Результати класифікації по МГУА 3 урахуванням доз добутаміну}

Як було сказано раніше, отримані моделі оцінені за показниками точності, чутливості, специфічності та коефіцієнту кореляції Метьюза (ККМ) на: навчальній вибірці (що складала 70\% від загальної), тестовій вибірці (20\%) і екзаменаційній вибірці (10\%).

В табл. 1 вказані оцінки моделей МГУА для СТЕ 3 дозою добутаміну 0 мкг (тобто в стані спокою).

Таблиця 1. Характеристика моделей МГУА в стані спокою

\begin{tabular}{|c|c|c|c|}
\hline Вибірка & Позиція ЕхоКГ & Точність & ККМ \\
\hline \multirow{2}{*}{$\begin{array}{c}\text { Навчальна } \\
\text { (70\%) }\end{array}$} & 4-саm & $83.8 \%$ & 0.665 \\
\cline { 2 - 4 } & 2-cam & $86.3 \%$ & 0.725 \\
\cline { 2 - 4 } & long & $84.3 \%$ & 0.668 \\
\hline \multirow{3}{*}{ Тестова (20\%) } & 4-cam & $82.1 \%$ & 0.627 \\
\cline { 2 - 4 } & 2-cam & $85.1 \%$ & 0.702 \\
\cline { 2 - 4 } & long & $82.3 \%$ & 0.624 \\
\hline \multirow{2}{*}{$\begin{array}{c}\text { Екзаменаційна } \\
(10 \%)\end{array}$} & 4-cam & $81.7 \%$ & 0.638 \\
\cline { 2 - 4 } & 2-cam & $85.3 \%$ & 0.703 \\
\cline { 2 - 4 } & long & $82.1 \%$ & 0.621 \\
\hline
\end{tabular}

Точність за тестовою та екзаменаційною вибірками знаходилась у межах від 81.7 до 85.3 відсотків, тобто була досить високою. Значення ККМ на даних вибірках також доволі високі (від 0.621 до 0.703 ), таким чином можна сказати, що отримані моделі є балансними.

В табл. 2 вказані оцінки моделей МГУА для СТЕ 3 дозою добутаміну 10 мкг.

Таблиця 2. Характеристики моделей МГУА при дозі добутаміну 10 мкг

\begin{tabular}{|c|c|c|c|}
\hline Вибірка & $\begin{array}{c}\text { Позиція } \\
\text { ЕхоКГ }\end{array}$ & Точність & ККМ \\
\hline \multirow{2}{*}{$\begin{array}{c}\text { Навчальна } \\
(70 \%)\end{array}$} & 4-cam & $93.9 \%$ & 0.877 \\
\cline { 2 - 4 } & 2 -cam & $92.3 \%$ & 0.843 \\
\cline { 2 - 4 } & long & $92.4 \%$ & 0.845 \\
\hline \multirow{3}{*}{ Тестова (20\%) } & 4-cam & $93.9 \%$ & 0.877 \\
\cline { 2 - 4 } & 2-cam & $91.4 \%$ & 0.827 \\
\hline \multirow{2}{*}{$\begin{array}{c}\text { Екзаменаційна } \\
(10 \%)\end{array}$} & long & $91.1 \%$ & 0.816 \\
\cline { 2 - 4 } & 2-cam & $92.7 \%$ & 0.854 \\
\cline { 2 - 4 } & long & $92.1 \%$ & 0.839 \\
\hline
\end{tabular}

По ній можна сказати, що при застосуванні тестової та екзаменаційної вибірки результати були дещо вищими, ніж для стану спокою i знаходились у межах від 92.1 до 92.7 відсотків. Також, на відміну від попереднього варіанту, тут значення ККМ вийшли дуже високими (від 0.839 до 0.854).

В табл. 3 вказані оцінки моделей МГУА для СТЕ $з$ дозою добутаміну 20 мкг.

Таблиця 3. Характеристики моделей МГУА при дозі добутаміну 20 мкг

\begin{tabular}{|c|c|c|c|}
\hline Вибірка & Позиція ЕхоКГ & Точність & ККМ \\
\hline \multirow{2}{*}{$\begin{array}{c}\text { Навчальна } \\
(70 \%)\end{array}$} & 4-саm & $89.7 \%$ & 0.785 \\
\cline { 2 - 4 } & 2-cam & $89.8 \%$ & 0.79 \\
\cline { 2 - 4 } & long & $93.2 \%$ & 0.836 \\
\hline \multirow{3}{*}{ Тестова (20\%) } & 4-cam & $87.7 \%$ & 0.741 \\
\cline { 2 - 4 } & 2-cam & $90.8 \%$ & 0.815 \\
\cline { 2 - 4 } & long & $93.9 \%$ & 0.823 \\
\hline \multirow{2}{*}{$\begin{array}{c}\text { Екзаменаційна } \\
(10 \%)\end{array}$} & 4-cam & $88.6 \%$ & 0.768 \\
\cline { 2 - 4 } & 2-cam & $90.9 \%$ & 0.811 \\
\cline { 2 - 4 } & long & $90.2 \%$ & 0.78 \\
\hline
\end{tabular}

Також досить високими були величини точності, отримані на тестовій та екзаменаційній вибірках для дози добутаміну 20 мкг. Вони знаходились у межах від 88.6 до 90.9 відсотків. Аналогічним чином вийшли дуже високими значення ККМ (від 0.768 до 0.811).

В табл. 4 вказані оцінки моделей МГУА для СТЕ $з$ дозою добутаміну 40 мкг.

Для найбільш жорстких умов ехострестесту при дозі добутаміну 40 мкг результати тестування знаходились у межах від 88.5 до 97.4 відсотків. Значення ККМ вийшли дуже високими (від 0.761 до 0.947).

Таблиця 4. Характеристики моделей МГУА при дозі добутаміну 20 мкг

\begin{tabular}{|c|c|c|c|}
\hline Вибірка & $\begin{array}{c}\text { Позиція } \\
\text { ЕхоКГ }\end{array}$ & Точність & ККМ \\
\hline \multirow{2}{*}{$\begin{array}{c}\text { Навчальна } \\
(70 \%)\end{array}$} & 4-саm & $94.8 \%$ & 0.895 \\
\cline { 2 - 4 } & 2-cam & $96.5 \%$ & 0.927 \\
\cline { 2 - 4 } Тестова (20\%) & long & $88.2 \%$ & 0.742 \\
\hline & 4-cam & $94.1 \%$ & 0.873 \\
\cline { 2 - 4 } & 2-cam & $95.4 \%$ & 0.898 \\
\hline \multirow{3}{*}{$\begin{array}{c}\text { Екзаменаційна } \\
(10 \%)\end{array}$} & long & $93.4 \%$ & 0.853 \\
\cline { 2 - 4 } & 2-cam & $88.5 \%$ & 0.761 \\
\cline { 2 - 4 } & long & $97.4 \%$ & 0.947 \\
\hline & & & 0.834 \\
\hline
\end{tabular}

\section{2. Результати класифікації по МГУА без врахування доз добутаміну}

В табл. 5 вказані оцінки моделей для усіх позицій СТЕ без урахування доз добутаміну. 
Таблиця 5. Характеристики діагностичних МГУА моделей у просторі “норма - патологія"

\begin{tabular}{|c|c|c|c|}
\hline Вибірка & $\begin{array}{c}\text { Позиція } \\
\text { ЕхоКГ }\end{array}$ & Точність & ККМ \\
\hline \multirow{3}{*}{ Навчальна (70\%) } & 4-саm & $74.5 \%$ & 0.486 \\
\cline { 2 - 4 } & 2 -cam & $79.8 \%$ & 0.595 \\
\cline { 2 - 4 } & long & $80.8 \%$ & 0.596 \\
\hline \multirow{3}{*}{ Тестова (20\%) } & 4-cam & $76 \%$ & 0.511 \\
\cline { 2 - 4 } & 2-cam & $79 \%$ & 0.584 \\
\cline { 2 - 4 } & long & $79.4 \%$ & 0.572 \\
\hline \multirow{2}{*}{$\begin{array}{c}\text { Екзаменаційна } \\
(10 \%)\end{array}$} & 4-cam & $76 \%$ & 0.511 \\
\cline { 2 - 4 } & 2-cam & $79 \%$ & 0.584 \\
\cline { 2 - 4 } & long & $79.4 \%$ & 0.572 \\
\hline
\end{tabular}

Точність при застосуванні тестової та екзаменаційної вибірок була дещо нижчою, ніж у попередньому дослідженні - від 76\% до 79.4\%. Значення ККМ вийшли високими (від 0.572 до 0.584), проте меншими ніж в минулих прикладах.

Таким чином, можна сказати, що більша деталізація умов побудови моделей (позиція СТЕ при обстеженнях та урахування доз добутаміну) сприяють покращенню класифікаційних характеристик моделей, побудованих методом МГУА.

\section{VII. ВИСНОВКИ}

Метод групового урахування аргументів при застосуванні текстурного аналізу та ехострестестів дозволяє побудувати алгоритми 3 досить високими, або прийнятними діагностичними характеристиками. Більша деталізація умов побудови моделей дозволяє отримати моделі кращої якості. Дослідження із застосуванням моделей, побудованих методом групового урахування аргументів, заслуговують на подальше продовження.

\section{ПЕРЕЛІК ПОСИЛАНЬ}

[1] Feng, X., Jiang, Y., Yang, X., et al. Computer vision algorithms and hardware implementations: A survey / 2019. 309-320 p. DOI: 10.1016/j.vlsi.2019.07.005.

[2] Criminisi, A. Machine learning for medical images analysis / 2016. 91-93 p. DOI: 10.1016/j.vlsi.2019.07.005.

[3] Voigt, J. U., Pedrizzetti, G., Lysyansky, P., et al. Definitions for a common standard for 2D speckle tracking echocardiography: consensus document of the EACVI/ASE/Industry Task Force to standardize deformation imaging. European heart journal cardiovascular Imaging. 2015. Vol. 16, No. 1. pp. 1-11. DOI: 10.1093/ehjci/jeu184.

[4] Lazoryshynets, V. V., Kovalenko, V. M., Rudenko, A. V., et al. Визначення загального стандарту для 2D-спекл-тре-кінг ехокардіографії (Проект консенсусу робочої групи Асоціації серцево-судинних хірургів України та Українського товариства кардіологів). Cardiology and cardiac surgery: continuous professional development. 2019. C. 105-129. DOI: 10.30702/ccs.201905.02.2dst105129.
[5] Ивахненко, А. Г., Степашко, В. С. Помехоустойчивость моделирования: Киев: Наук. думка, 1985. $216 \mathrm{c}$.

[6] Павлов, А. В., Степашко, В. С., Кондрашова, Н. В. Эффективные методы самоорганизации моделей: Киев: Академперіодика, 2014. 197c.

[7] Nargesian, F., Samulowitz, H., Khurana, U., et al. Learning feature engineering for classification: IJCAI International Joint Conference on Artificial Intelligence, 17. pp. 2529-2535. DOI: 10.24963/ijcai.2017/352.

[8] Molinari, F., Caresio, C., Acharya, U. R., et al. Advances in Quantitative Muscle Ultrasonography Using Texture Analysis of Ultrasound Images. Ultrasound in Medicine and Biology. 2015. Vol. 41, No. 9. pp. 2520-2532. DOI: 10.1016/j.ultrasmedbio.2015.04.021.

[9] Kavitha, P., Prabakaran, S. Designing a feature vector for statistical texture analysis of brain tumor. International Journal of Engineering and Advanced Technology. 2019. Vol. 8, No. 5. pp. 1228-1230. DOI: 10.20944/preprints201906.0166.v1.

[10] Настенко, Є. А., Дикан, I. М., Тарасюк, Б. А., та ін. Класифікація станів печінки при дифузних захворюваннях на основі статистичних показників текстури ультразвукових зображень та МГУА. Індуктивне моделювання складних систем. 2019. Vol. 11. C. 54-66.

[11] Настенко, Є. А., Павлов, В. А., Носовець, О., та ін. Застосування текстурного аналізу у вирішенні задачі класифікації медичних зображень. Біомедична інженерія i технологія. 2020. Vol. 4. C. 69-82. DOI: 10.20535/26178974.2020.4.221876

[12] Contreras-Ojeda, S. L., Sierra-Pardo, C., DominguezJimenez, J. A., et al. Texture Analysis of Ultrasound Images for Pneumonia Detection in Pediatric Patients: 2019 22nd Symposium on Image, Signal Processing and Artificial Vision, STSIVA 2019Conference Proceedings, Institute of Electrical and Electronics Engineers Inc., 01.April.19. P. 4. DOI: 10.1109/STSIVA.2019.8730238.

[13] Baidya Kayal, E., Kandasamy, D., Khare, K., et al. Texture analysis for chemotherapy response evaluation in osteosarcoma using MR imaging. NMR in Biomedicine. 2021. Vol. 34, No. 2. P. 17. DOI: $10.1002 / \mathrm{nbm} .4426$.

[14] Rini Novitasari, D. C., Lubab, A., Sawiji, A., et al. Application of feature extraction for breast cancer using one order statistic, glcm, glrlm, and gldm. Advances in Science, Technology and Engineering Systems. 2019. Vol. 4, No. 4. pp. 115-120. DOI: 10.25046/aj040413.

[15] Zayed, N., Elnemr, H. A. Statistical Analysis of Haralick Texture Features to Discriminate Lung Abnormalities. International Journal of Biomedical Imaging. 2015. Vol. 2015. P. 7. DOI: $10.1155 / 2015 / 267807$.

[16] Li, D., Armaghani, D. J., Zhou, J., et al. A GMDH Predictive Model to Predict Rock Material Strength Using Three Non-destructive Tests. Journal of Nondestructive Evaluation. 2020. Vol. 39, No. 4. P. 81. DOI: 10.1007/s10921-020-00725-x.

[17] Tian, C., Fei, L., Zheng, W., et al. Deep learning on image denoising: An overview / 2020. 251-275 p. DOI: 10.1016/j.neunet.2020.07.025.

[18] Chicco, D., Jurman, G. The advantages of the Matthews correlation coefficient (MCC) over F1 score and accuracy in binary classification evaluation. BMC Genomics. 2020. Vol. 21, No. 1. P. 6. DOI: 10.1186/s12864-019-6413-7.

[19] GMSH Shell DS Video Tutorials: URL: https://gmdhsoftware.com/tutorials-ds.

\section{REFERENCES}

[1] X. Feng, Y. Jiang, X. Yang, M. Du, and X. Li, "Computer vision algorithms and hardware implementations: A survey", Integration, vol. 69. pp. 309-320, 2019, DOI: 10.1016/j.vlsi.2019.07.005. 
[2] A. Criminisi, "Machine learning for medical images analysis", Medical Image Analysis, vol. 33. pp. 91-93, 2016, DOI: 10.1016/j.media.2016.06.002.

[3] J. U. Voigt et al., "Definitions for a common standard for 2D speckle tracking echocardiography: consensus document of the EACVI/ASE/Industry Task Force to standardize deformation imaging", Eur. Heart J. Cardiovasc. Imaging, vol. 16, no. 1, pp. 1-11, 2015, DOI: 10.1093/ehjci/jeu184.

[4] V. V. Lazoryshynets et al., "Definition for a Common Standard for 2D Speckle-Track-ing Echocardiography (The Association of Cardiovascular Surgeons of Ukraine and the Ukrainian Society of Cardiology Working Group Draft Consensus)", Cardiol. Card. Surg. Contin. Prof. Dev., pp. 105-129, 2019, DOI: 10.30702/ccs.201905.02.2dst105129 (in Ukrainian).

[5] A. G. Ivakhnenko and V. S. Stepashko, Noise immunity of modeling. Kiev: Nauk. dumka, 1985 (in Russian).

[6] A. V. Pavlov, V. S. Stepashko, and N. V. Kondrashova, Effective methods of models' self-organization. Kiev: Akademperiodika, 2014 (in Russian).

[7] F. Nargesian, H. Samulowitz, U. Khurana, E. B. Khalil, and D. Turaga, "Learning feature engineering for classification", in IJCAI International Joint Conference on Artificial Intelligence, 2017, vol. 0, pp. 2529-2535, DOI: 10.24963/ijcai.2017/352.

[8] F. Molinari, C. Caresio, U. R. Acharya, M. R. K. Mookiah, and M. A. Minetto, "Advances in Quantitative Muscle Ultrasonography Using Texture Analysis of Ultrasound Images", Ultrasound Med. Biol., vol. 41, no. 9, pp. 2520-2532, Sep. 2015, DOI: 10.1016/j.ultrasmedbio.2015.04.021.

[9] P. Kavitha and S. Prabakaran, "Designing a feature vector for statistical texture analysis of brain tumor", Int. J. Eng. Adv. Technol., vol. 8, no. 5, pp. 1228-1230, 2019, DOI 10.20944/preprints201906.0166.v1.

[10] Ie. A. Nastenko et al., "GMDH Classification for Diffuse Liver Disease States Based on Statistical Features of the Ultrasound Images Texture", Induktivne modelliuvannia skladnih system, vol. 11, pp. 54-66, 2019 (in Ukranian).

[11] Ie. A. Nastenko et al., "Texture Analysis Application in Medical Images Classification Task Solving", Biomedichna ingeneriya i tekhnologiya, vol. 4, pp. 69-82, Dec. 2020, DOI: 10.20535/2617-8974.2020.4.221876 (in Ukrainian).

[12] S. L. Contreras-Ojeda, C. Sierra-Pardo, J. A. Dominguez-Jimenez, J. Lopez-Bueno, and S. H. Contreras-Ortiz, "Texture Analysis of Ultrasound Images for Pneumonia Detection in Pediatric Patients", in 2019 22nd Symposium on Image, Signal Processing and Artificial Vision, STSIVA 2019-Conference Proceedings, Apr. 2019, p. 4, DOI: 10.1109/STSIVA.2019.8730238.

[13] E. Baidya Kayal, D. Kandasamy, K. Khare, S. Bakhshi, R. Sharma, and A. Mehndiratta, "Texture analysis for chemotherapy response evaluation in osteosarcoma using MR imaging", NMR Biomed., vol. 34, no. 2, p. 17, Feb. 2021, DOI: $10.1002 / \mathrm{nbm} .4426$.

[14] D. C. Rini Novitasari, A. Lubab, A. Sawiji, and A. H. Asyhar, "Application of feature extraction for breast cancer using one order statistic, glcm, glrlm, and gldm", Adv. Sci. Technol. Eng. Syst., vol. 4, no. 4, pp. 115-120, 2019, DOI: 10.25046/aj040413.

[15] N. Zayed and H. A. Elnemr, "Statistical Analysis of Haralick Texture Features to Discriminate Lung Abnormalities", Int. J. Biomed. Imaging, vol. 2015, p. 7, 2015, DOI: $10.1155 / 2015 / 267807$.

[16] D. Li, D. J. Armaghani, J. Zhou, S. H. Lai, and M. Hasanipanah, "A GMDH Predictive Model to Predict Rock Material Strength Using Three Non-destructive Tests", J. Nondestruct. Eval., vol. 39, no. 4, p. 81, Dec. 2020, DOI: 10.1007/s10921-020-00725-x.

[17] C. Tian, L. Fei, W. Zheng, Y. Xu, W. Zuo, and C. W. Lin, "Deep learning on image denoising: An overview", Neural Networks, vol. 131. pp. 251-275, 2020, DOI: 10.1016/j.neunet.2020.07.025.

[18] M. I. Radaideh and T. Kozlowski, “Analyzing nuclear reactor simulation data and uncertainty with the group method of data handling", Nucl. Eng. Technol., vol. 52, no. 2, pp. 287-295, Feb. 2020, DOI: 10.1016/j.net.2019.07.023.

[19] "GMSH Shell DS Video Tutorials". https://gmdhsoftware.com/tutorials-ds. 


\title{
ПРИМЕНЕНИЕ МЕТОДА ГРУППОВОГО УЧЁТА АРГУМЕНТОВ ДЛЯ ПОСТРОЕНИЯ АЛГОРИТМОВ ДИАГНОСТИКИ ИШЕМИЧЕСКОЙ БОЛЕЗНИ СЕРДЦА
}

\author{
Настенко Е. ${ }^{1,2}$, с.н.с., д.б.н., к.Т.н. \\ nastenko.e@gmail.com \\ Максименко В.Б. ${ }^{1,2}$, проф., д.м.н. \\ maksymenko.vitaliy@gmail.com \\ Поташев С.В. ${ }^{2}$, доц., к.М.н. \\ potashovsv77@gmail.com \\ Павлов В. . $^{1}$, доц., к.т.н. \\ pavlov.vladimir264@gmail.com \\ Бабенко В.О. ${ }^{1}$, магистр \\ vbabenko2191@gmail.com \\ Рысин С.B. ${ }^{1,2}$, ст. препод. \\ drunk umka@yahoo.com \\ Матвийчук $\boldsymbol{A . B .}{ }^{1}$, аспирант \\ sasha.matviich@gmail.com \\ Лазоришинец В.В. ${ }^{2}$, проф., д.м.н. \\ lazorch@ukr.net \\ ${ }^{1}$ Национальный технический университет Украины \\ “Киевский политехнический институт имени Игоря Сикорского”, \\ м. Киев, Украина \\ ${ }^{2}$ Національний институт сердечно-сосудистой хирургии имени М.М. Амосова, \\ м. Киев, Украина
}

Peферат-Проблематика. Метод группового учета аргументов является достаточно недооцененным инструментом для получения высокоточных прогностических моделей. Первый вариант искусственной нейронной сети (которые пользуются огромной популярностью в мире машинного обучения) был получен в 1965 году украинским ученым Алексеем Ивахненко, который как раз использовал метод группового учета аргументов для обучения сети. Известно, что данный подход имеет место практически в любой проблематике, и не исключением является задача распознавания ишемической болезни сердца по видеоданным спекл-трекинг эхокардиографии. Решение подобной задачи является актуальным, поскольку это позволит анализировать эхокардиограммы даже если они не оснащены технологией спекл-трекинг.

Цель. Методом группового учёта аргументов по данным спекл-трекинг эхокардиографии построить классификационные алгоритмы диагностики нарушений кинематики сокращений левого желудочка сердца у больных ишемической болезнью сердца в условиях состояния покоя, и при применении эхостресстеста с добутаминовой пробой.

Методика реализации. Национальным институтом сердечно-сосудистой хирургии имени Н.Н. Амосова были предоставлены видеоданные, полученные с помощью метода спекл-трекинг эхокардиографии, которым было обследовано 56 пациентов с подозрением на ишемическую болезнь сердца. Среди них только у 16 пациентов патологии выявлено не было. Эхокардиография регистрировалась в В-режиме по трем позициям: долгой оси, 4-камерной и 2-камерной позициях. Всего для исследования были использованы 6245 кадров видеопотока: 1871 - без нарушений сердечной деятельности, и 4374 - при наличии патологии во время обследования.

Результаты исследования. Методом группового учета аргументов было получено 12 моделей классификации с учетом доз добутамина $(0,10,20$ и 40 мкг), точность которых на экзаменационной выборке варьировалась от $81.7 \%$ до 97.4\%. Также были получены 3 модели классификации без учета доз добутамина, которые на экзаменационной выборке показали точность в пределах $75.2-82.2 \%$.

Bblвoдbl. Полученные высокоточные модели классификации методом группового учета аргументов. Данные модели могут быть применены для анализа ехокардиограм, полученных в В-режиме на оборудовании, не оснащенного технологией спекл-трекинг. Ключевые слова: метод группового учёта аргументов; классификация; спекл-трекинг эхокардиография; эхостресстест с добутамином; ишемическая болезнь сердияа 


\title{
GROUP METHOD OF DATA HANDLING APPLICATION IN COSTRUCTING OF CORONARY HEART DISEASE DIAGNOSING ALGORITHMS
}

\author{
Nastenko Ie.A. ${ }^{1,2}$, Senior Research Officer, \\ Doctor of Biological Sciences, \\ $\mathrm{Ph} . \mathrm{D}$. of Technical Sciences \\ nastenko.e@gmail.com \\ Maksymenko V.B. ${ }^{1,2}$, Professor, \\ Doctor of Medical Sciences \\ maksymenko.vitaliy@gmail.com \\ Potashev S.V. ${ }^{2}$, Docent, \\ $\mathrm{Ph} . \mathrm{D}$. of Medical Sciences \\ potashovsv77@gmail.com \\ Pavlov V.A. ${ }^{1}$, Docent, \\ $\mathrm{Ph} . \mathrm{D}$. of Technical Sciences \\ pavlov.vladimir264@gmail.com \\ Babenko V.O. ${ }^{1}$, Master \\ vbabenko2191@gmail.com \\ Rysin $S . V^{\mathbf{1 , 2}}$, Senior Lecturer \\ drunk_umka@yahoo.com \\ Matviichuk O.V. ${ }^{1}$, Postgraduate Student \\ sasha.matviich@gmail.com \\ Lazoryshinets $V \cdot V^{2}$, Professor, \\ Doctor of Medical Sciences \\ lazorch@ukr.net \\ Faculty of Biomedical Engineering \\ ${ }^{1}$ NTUU "Igor Sikorsky Kyiv Polytechnic Institute", \\ Kyiv, Ukraine \\ ${ }^{2}$ National M. Amosov`Institute of Cardiovascular Surgery, \\ Kyiv, Ukraine
}

\footnotetext{
Abstract-Background. Group method of data handling is a rather underestimated tool for obtaining highly accurate predictive models. The first version of an artificial neural network (which is very popular in the world of machine learning) was obtained in 1965 by the Ukrainian scientist Aleksey Ivakhnenko, who just used the group method of data handling to train the network. It is known that this approach takes place in almost any problematics, and the problem of recognizing coronary heart disease using video data from speckle-tracking echocardiography is not an exception. The solution to this problem is relevant, since it will allow analyzing echocardiograms even if they are not equipped with speckle-tracking technology.

Objective. According to the data of speckle-tracking echocardiography construct classification algorithms by using the group method of data handling for diagnosing violations of the kinematics of left ventricular contractions in patients with coronary heart disease under conditions of rest, and when using echostresstest with dobutamine.

Methods. National Institute of Cardiovascular Surgery provided video data obtained using the speckle-tracking echocardiography method, which examined 56 patients with suspected coronary heart disease. Among them, only 16 patients had no pathology. Echocardiography was recorded in B-mode in three positions: long axis, 4-chamber, and 2-chamber positions. In total, 6245 frames of the video stream were used for the study: 1871 - without cardiac abnormalities, and 4374 - in the presence of pathology during the examination.

Results. Using the group method of data handling, 12 classification models were obtained, taking into account the doses of dobutamine $(0,10$, 20 , and $40 \mathrm{mcg}$ ), the accuracy of which on the examination sample varied from $81.7 \%$ to $97.4 \%$. Also, 3 classification models were obtained without taking into account the doses of dobutamine, which on the examination sample showed an accuracy within 75.2-82.2\%.

Conclusions. The high-precision classification models were obtained by the group method of data handling. These models can be used to analyze echocardiograms obtained in B-mode on equipment, which is not using speckle-tracking technology.
}

Keywords: group method of data handling; classification; speckle tracking echocardiography; echostresstest with dobutamine; coronary heart disease. 